\title{
Analysis of the Risk Influence Factors in Apartment Building Development Projects
}

\author{
Lee, Sung- $-\mathrm{Ho}^{1} \quad$ Kim, Sun-Kuk ${ }^{1} \quad$ Suh, Sang-Wook ${ }^{2 *}$ \\ Department of Architectural Engineering, Kyung Hee University, 1732 Deogyeong-dearo, Giheung-gu, Yongin-si, \\ Gyeonggi-do, 446-701, Republic of Korea ${ }^{1}$ \\ Department of Architecture Engineering, Gachon University, 1342 Seongnam-daero, Sujeong-gu, Seongnam-si, \\ Gyeonggi-do, 461-701, Republic of Korea ${ }^{2}$
}

\section{Abstract}

There have been few attempts made to perform a systematic analysis of the various risk influence factors in building development projects. This study suggests an analysis of the risk influence factors in the process of feasibility studies for apartment building development projects. To reflect the voice of professionals, surveys were carried out. In addition, an FD-AHP method was applied to identify the importance of the risk influence factors. Through the surveys, major risk factors were separately identified as direct and/or indirect elements. An analysis of risk influence factors supports an effective feasibility study of apartment building development projects.

Keywords : apartment building development projects, risk influence factor, FD - AHP

\section{Introduction}

Since the legislation of the Asset-backed Securities(ABS) Act in 1998, there has been a surge in the number of construction projects promoted through project financing (hereinafter $\mathrm{PF})$ [1]. In particular, many construction companies have actively participated in apartment building construction projects, which offer a relatively higher predicted return compared with other construction projects[2]. Companies that participated in apartment building construction projects during the housing boom from 2004 to 2007 made a considerable profit[3].

Received : April 3, 2013

Revision received : April 30, 2013

Accepted : May 9, 2013

* Corresponding author : Suh, Sang-wook

[Tel: 82-31-750-5300, E-mail: suh@gachon.ac.kr]

(c)2013 The Korea Institute of Building Construction, All rights reserved.
With the recession in the housing market influenced by the global financial crisis in 2008, many apartments have remained unsold[4], which has caused many construction companies to suffer financial hardship and discontinue their construction projects. From this it is evident that apartment building construction projects can bring high returns to companies during a housing market boom, but can cause a much higher loss during a market recession.

In addition, an apartment building construction project is generally large and thus can give rise to diverse kinds of risk, and the consequences of such risk can not only affect construction companies but also general consumers, as well as the national economy as a whole[2].

It is thus an over-simplification to say that the financial crisis was the cause of financial losses related to recession in the housing market. It is important to identify the other problems that need 
to be resolved, including the incompetence of project participants who pushed projects during the housing boom without any scientific and systemic analysis of diverse risk factors. An apartment building construction project is generally reviewed in several steps. That is, it is first reviewed by a developer, and then by the construction company to check its feasibility because it requires a surety for $\mathrm{PF}$, and then by a financial company to check the business risk for the payment of $\mathrm{PF}$. The main items checked during those reviews are the factors that determine its feasibility, but they can also be risk factors as well. Here, it is noted that many projects determined safe in the several-step reviews turned out to bear a high risk[2].

In the previous studies related to apartment building construction projects, feasibility analysis, weight evaluation by analyzing risk factors, and response to risk have been actively analyzed. However, the research findings of the studies have a long way to go before they can be applied to decision-making in the field. Several factors have an intertwining and dynamic effect on an apartment building construction project rather than having effects individually. In addition, too much consideration of the qualitative factors has prevented the business risk from being systematically analyzed.

Therefore, a feasibility analysis model is needed, in which the project participants can check any changes in the relationship between the factors in a simple and quick manner.

Previous studies on the risk factors of an apartment building construction project can be categorized into feasibility analysis, weight evaluation by analyzing risk factors, and responses to risk. First of all, the feasibility analysis includes the feasibility analysis process for an apartment project[5], the feasibility analysis model building for an apartment project[6], and the development of an analysis model for a developer-requested housing project[7], but the previous studies have focused only on feasibility analysis process and analysis methodology. The studies of weight evaluation through factor analysis include the importance of risk factors for effective management at the pre-project planning phase for the domestic development project[8], risk management of apartment reconstruction projects [9], and quantification of risk factors in real estate development projects, in all of which the importance of risk factors was estimated through survey questionnaires; however, the relationship between the risk and the utilization of the findings has not been clearly elucidated. In terms of studies on the response to risk, there have been studies on the method of risk management in real estate development projects[11], and the method of risk management in housing projects[12], but these just analyzed the risk factors and presented how to respond to an individual factor.

However, the previous studies have mostly focused on consumer preference for apartment development projects and a political alternative for the business resuscitation, but there has been scant research reflecting the importance of the risk factors in the feasibility analysis. An importance analysis of risk factors helps prevent inappropriate apartment projects from being taken up in advance, as it enables the project participants to easily understand the sensitivity and changes in business profits caused by the business environment. Therefore, this is a preliminary study for the development of a feasibility analysis model, and aims to analyze the importance of risk factors for economic feasibility analysis. Risk factors are verified as having an impact on the feasibility analysis in this study in order to analyze the 
impact of the factors on a project in advance, and this can be utilized as a tool in establishing a strategy for the successful completion of a project.

\section{Preliminary review}

\subsection{The concept of an apartment development project}

\subsubsection{The concept of an apartment development project}

A development project involves doing something to realize tangible and intangible value by incorporating finance, labor, and resources based on the business analysis of each phase for each participant. That is, the purpose of a development project is to create more profits by achieving an increase in value when the construction of a building is completed. With higher standard of living and the recovery of the construction business, more construction companies are taking up development projects rather than simply building structures. Aware of the new landscape of the construction industry, many companies are seeking changes in their business[13].

\subsubsection{Classification of development projects}

Development projects can be classified into facility and development method, sales(operation) method, and corporate activities. More specifically, residential facilities can be further divided into apartments, single houses and country houses, while commercial facilities are sorted into those for selling, for business and for lodging. In addition, there are industrial facilities, public facilities, and other facilities including urban development facilities. Table 1 indicates the system for classifying development projects[14]. In other words, not only should an accurate analysis of the business be performed, but a clear understanding of the jobs and tasks by phase should be arrived at as well, an analysis of business characteristics by development and sales(operation) method should be conducted, and the establishment of development strategies and evaluation of risk factors should be performed from the perspective of corporate activity. In addition, the business characteristics vary depending on a project. Pre-development strategies should be set up by taking the risk factors into account, and the items to be reviewed should be analyzed in advance.

Table 1. Classification of architectural development projects

\begin{tabular}{|c|c|}
\hline Classification & Item \\
\hline \multirow{5}{*}{ Facilities } & $\begin{array}{c}\text { Residential facilities: apartment, single, country } \\
\text { house }\end{array}$ \\
\hline & $\begin{array}{c}\text { Commercial facilities: selling, business, lodging, } \\
\text { etc. }\end{array}$ \\
\hline & Industry facilities: factory, power plant, etc. \\
\hline & $\begin{array}{c}\text { Public facilities: government and public offices, } \\
\text { road, harbor, etc. }\end{array}$ \\
\hline & Et cetera facilities \\
\hline $\begin{array}{l}\text { Development } \\
\text { method }\end{array}$ & $\begin{array}{l}\text { Renewal, rebuild, public development, land } \\
\text { ownership, social overhead capital }\end{array}$ \\
\hline Operation system & Sale in lots, lease, direct management \\
\hline \multirow{2}{*}{ Corporate activities } & $\begin{array}{l}\text { Operation: production facilities, operation } \\
\text { facilities }\end{array}$ \\
\hline & $\begin{array}{l}\text { Business: residential construction, building, } \\
\text { leisure, etc. }\end{array}$ \\
\hline
\end{tabular}

\subsection{Influence of feasibility analysis and items to be reviewed}

The feasibility of an apartment development is analyzed at an initial phase. The feasibility analysis can be defined as a review of the capability to perform the project, the possibility of successful completion, or the determination of the viability of several plans to find the optimal one for investment. It is a systematic and composite analysis of a series of processes of an investment alternative from legal, physical, technical and economic perspectives[15]. Therefore, it should be performed for several alternatives at the pre-construction phase, because the decisions 
made at the initial phase have a great impact on the entire project[16].

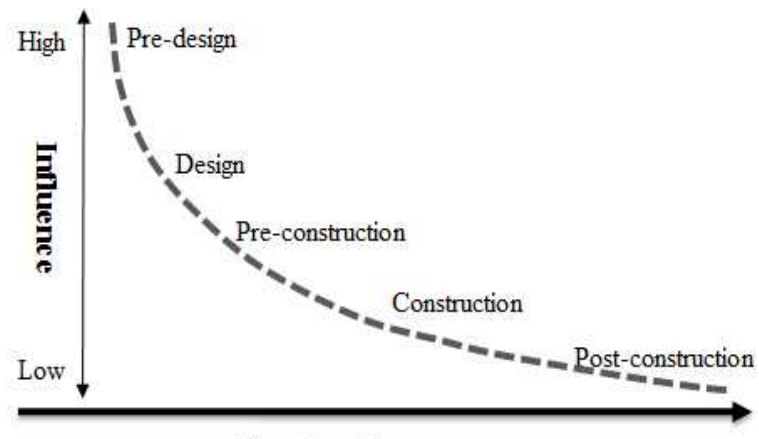

Construction process

Figure 1. Influence of construction process

In addition, the items of the feasibility analysis clearly spell out the similarities of the important factors despite slight differences in the classification type and method for each individual business or undertaker. This may be because a project is affected by different social, environmental, legal, systemic and technical limitations and regulations. This can be outlined as in Table 2[3].

Table 2. Item of Feasibility study

\begin{tabular}{|c|c|c|}
\hline \multicolumn{2}{|c|}{ Classification } & Item \\
\hline \multirow{4}{*}{ Basic analysis } & Location & $\begin{array}{l}\text { Internal and external } \\
\text { environmental factors }\end{array}$ \\
\hline & $\begin{array}{l}\text { Law and } \\
\text { regulation }\end{array}$ & Land law, zoning law, etc. \\
\hline & Market & $\begin{array}{c}\text { Market demand, supply, buy and } \\
\text { sell }\end{array}$ \\
\hline & $\begin{array}{l}\text { Commercial } \\
\text { impact }\end{array}$ & $\begin{array}{l}\text { Population, volume of traffic, level } \\
\text { of consumption, urban planning }\end{array}$ \\
\hline \multirow{3}{*}{$\begin{array}{l}\text { Marketing } \\
\text { analysis }\end{array}$} & Format & $\begin{array}{l}\text { Internal, Interactive, organization, } \\
\text { person, place, social, etc }\end{array}$ \\
\hline & Sale price & $\begin{array}{l}\text { The market price, home sale } \\
\text { prices }\end{array}$ \\
\hline & $\begin{array}{l}\text { Sell in lots } \\
\text { assumption }\end{array}$ & Sales rate, dealing rate \\
\hline \multirow{3}{*}{$\begin{array}{l}\text { Financial } \\
\text { analysis }\end{array}$} & Income & Parcel price, \\
\hline & $\begin{array}{c}\text { Cost } \\
\text { accounting }\end{array}$ & $\begin{array}{l}\text { land cost, construction expenses, } \\
\text { normal management expense, etc. }\end{array}$ \\
\hline & $\begin{array}{l}\text { Analysis of } \\
\text { profitability }\end{array}$ & Cash-flow, NPV, IRR \\
\hline
\end{tabular}

\section{Analysis procedure of risk factors}

In this section, the risk factors that have an effect on an apartment development project are analyzed. The analysis procedure is illustrated in Figure 2.

First, the risk factors found to affect the conventional development projects were reviewed from previous studies and literature to derive the main risk factors having an influence on the feasibility analysis of an apartment development project.

Second, the risk factors extracted from the interviews with project participants were compared with those found through a questionnaire survey to derive the final risk factors for the apartment project.

Third, the hierarchical structure of the derived risk factors was established, and then the importance of the risk factors was set through the the Fussy Delphi -Analytic Hierarchy Process (FD-AHP).

Fourth, the order of risk factors was reset based on importance.

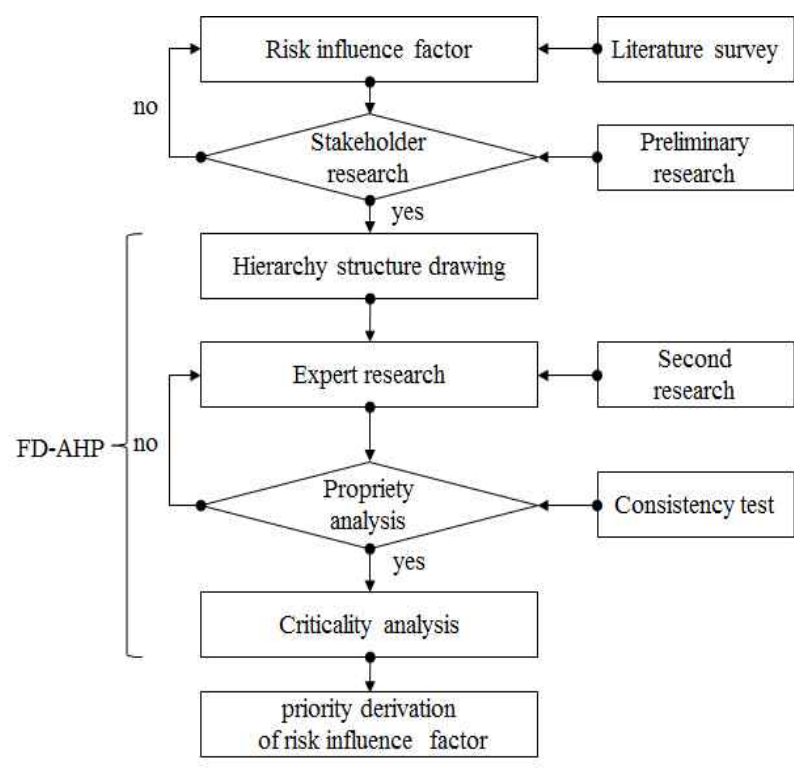

Figure 2. Analysis procedure of risk influence factors 


\subsection{Preliminary deduction of risk faction for the apartment development project}

There are internal and external risks in a development project, as it is affected not only by the intertwining risk factors but also by the uncertainty of diverse factors, including the working conditions[14]. Risk factors have been studied to obtain a clearer understanding.

Korea House Guarantee(KHG) classified 6 risk factors: conditions of location including housing supply rate, adjacent region, traffic environment and surrounding comfort conditions; form of the complex including the size of the complex and floor plan; sales rate in the neighborhood related with the variation of unsold new houses last month and the initial sales rate of neighboring apartments; variation of the composite price index for apartment sales; price index related with the sales price index; competitiveness in terms of brand preference for the builder; and composite assessment of the sales branch(marketability). Yoon[17] focused on the risk factors in the laws and legal regulations, market, financing, and construction for a real-estate development project, while Koo and Jeong[18] studied risk factors in development location setting, social market setting, and development planning setting. Hong[14] conducted a study by dividing risk factors into five sectors based on his extensive field experience as an expert in project development: regional conditions including housing supply and price; residential conditions including housing characteristics and apartment complex characteristics; location conditions including traffic environment, convenience facilities, and educational facilities; socio-political conditions including the brand of the builder, major market trend, and socio-political environment; and strengths and weaknesses. In addition, others have studied the risk factors by referring to other standards, but many apartment projects turn out to fail, which disproves the conventional approach to risk management. Therefore, this study derived the risk factors as shown in Figure 3 within the scope of this research through the preliminary selection based on the risk factors in the aforementioned apartment projects. The classification includes three large categories and 17 subcategories. The large categories consist of direct influential factors, indirect influential factors, and other factors. The direct category refers to factors that directly influence business or profits, such as parcel price, sales rate, construction expenses, land cost, financial cost, and period of project. The indirect category refers to risk factors that influence the success of the project but have no direct impact on the project, and includes the diffusion rate of houses in the neighborhood, adjacent range of the developer, transportation and surrounding comfort conditions, complex size, flat formation, brand preference for the builder, housing supply variation in the neighborhood, and sales price index.

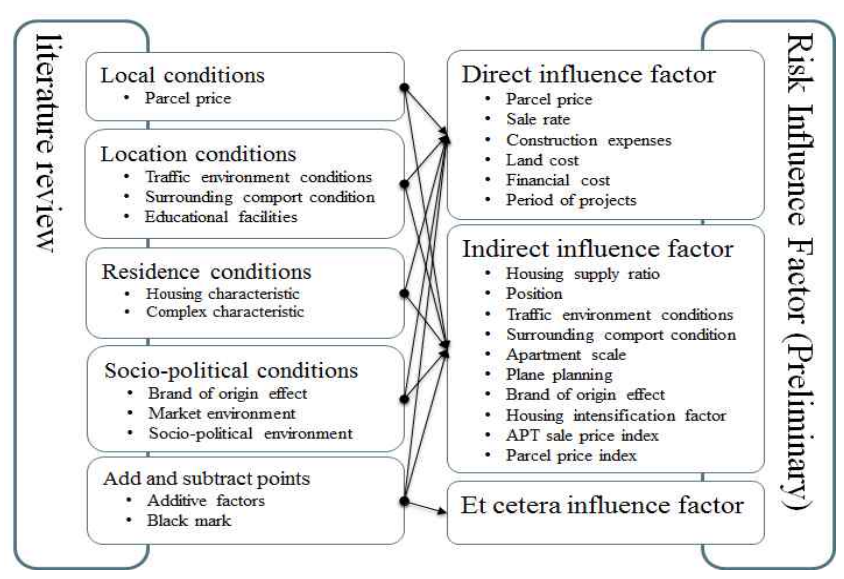

Figure 3. Preliminary risk influence factors

Lastly, the other category was included to reflect the other factors that have not been included in the previous studies but need to be considered in the feasibility analysis. 


\subsection{Importance of risk factors}

A survey was conducted by interviewing experts with 7-20 years of experience in apartment development projects based on the risk factors in Figure 3, and asking them to fill out a questionnaire. The survey and interview were conducted with 4 companies included in the top 10 company list made based on construction capability, and a private developer that has successfully provided more than 10,000 households of apartment buildings. Through the interview, the risk factors that were preliminarily selected were rearranged, and then the final risk factors selected were shown in Table 3.

Table 3. Risk influence factor

\begin{tabular}{|c|c|c|c|}
\hline \multicolumn{2}{|c|}{ Classification } & No. & Note \\
\hline \multirow{6}{*}{$\begin{array}{l}\text { Direct } \\
\text { Influence } \\
\text { factor } \\
\text { (A) }\end{array}$} & Parcel price & (A1) & \\
\hline & Sale rate & (A2) & \\
\hline & $\begin{array}{l}\text { Constructio } \\
n \text { expenses }\end{array}$ & (A3) & \\
\hline & Land cost & (A4) & $\begin{array}{l}\text { Average land purchase } \\
\text { price }\end{array}$ \\
\hline & $\begin{array}{c}\text { Financial } \\
\text { cost }\end{array}$ & (A5) & $\begin{array}{l}\text { PF, passive middle } \\
\text { payment, etc. }\end{array}$ \\
\hline & $\begin{array}{l}\text { Period of } \\
\text { projects }\end{array}$ & (A6) & \multirow{6}{*}{$\begin{array}{c}\text { Distance of convenience } \\
\text { facilities (school, } \\
\text { government and public } \\
\text { offices, etc) }\end{array}$} \\
\hline \multirow{5}{*}{$\begin{array}{l}\text { Indirect } \\
\text { Influence } \\
\text { factor } \\
\text { (B) }\end{array}$} & $\begin{array}{l}\text { Apartment } \\
\text { scale }\end{array}$ & (B1) & \\
\hline & Position & (B2) & \\
\hline & $\begin{array}{l}\text { Surrounding } \\
\text { comport } \\
\text { condition }\end{array}$ & (B3) & \\
\hline & $\begin{array}{l}\text { Brand of } \\
\text { origin effect }\end{array}$ & (B4) & \\
\hline & $\begin{array}{c}\text { Traffic } \\
\text { environment } \\
\text { conditions }\end{array}$ & (B5) & \\
\hline
\end{tabular}

In addition, the importance of the risk factors was analyzed using FA-AHP technique. To do this, the risk factors finally selected for the apartment project were hierarchized in terms of importance. In the hierarchization, the factors in the subcategories were used to evaluate the larger categories. The hierarchized risk factors are useful for project participants to make a composite evaluation. The highest hierarchy includes all risk factors for the apartment projects, and the next hierarchy includes the large categorization of direct risk factors(A) and indirect risk factors(B). The subcategory of the direct risk factors includes 6 factors: parcel price, sales rate, construction expenses, land cost, financial cost, and period of the project. The subcategory of the indirect risk factors includes 5 factors: complex size, adjacent region, surrounding comfort condition, brand preference, and traffic environment. In sum, 11 risk factors in the subcategory were finally selected.

\subsection{Importance analysis of the risk factors}

\subsubsection{Questionnaire survey}

In this research, risk factors were divided into 2 for larger categories and 11 for the sub categories to analyze the importance of the risk factors that influence the apartment projects. To determine the importance of the categorized risk factors, a questionnaire survey of experts was conducted. To improve the reliability of the survey results, the experts were limited to those who have experience in apartment development projects. Specifically, 5 questionnaires were collected from development planning teams, 14 questionnaires from sales teams and 4 from developers. The experts have 11.4 years of work experience in the field on average, and of the population, 14 experts have worked more than 10 years in the field. The data was collected from October 20, 2012 through November 20, 2012. We sent a total of 30 questionnaires to the experts, and collected 23 questionnaires, or $77 \%$ of those sent out.

Only the data found to be logically consistent through a consistency review was used. The data is found to be sound when it has a Constancy 
Index(C.I.) of less than 0.1, as shown in Eq.(1). Of the 23 questionnaires collected from the experts, 21 questionnaires or 92\% were found to be consistent, and the weight was calculated with them $[19,20]$.

$$
C . I=\frac{\lambda_{\max }-n}{n-1}
$$

$\lambda_{\max }:$ maximum eigenvalue $\mathrm{n}:$ matrix size

\subsubsection{Importance calculation}

The importance of the factors for the apartment projects was calculated based on the survey results using FD-AHP. The result of importance calculation is explained with the direct risk factors.

In the importance calculation of the subcategory, the expert responses were calculated into minimum, average and maximum because the responses were objectified using Triangularity Fuzzy Function.

Of the responses, the maximum and the minimum can be considered as extreme expressions of the expert's decision-making. The response with the most confidence that lies in between the maximum and the minimum can be expressed as optimal. The optimal value can be expressed as the geometric mean of the decision made by all the experts. The minimum, the optimal, and the maximum can be expressed as shown in Eq.(2). Here, $a$ is the minimum, $b$ is the geometric mean, and $c$ is the maximum[20].

$$
a=\operatorname{Min}\left[\widehat{a_{i j}}\right]_{k}, \quad b=\left(\prod_{k=1}^{n}\left[\widehat{a_{i j}}\right]_{k}\right)^{\frac{1}{n}}, c=\operatorname{Max}\left[\widehat{a_{i j}}\right]_{k}
$$

The data was arranged into the maximum, the maximum, and the optimal in a fuzzy matrix as shown in Table 4.

\begin{tabular}{|c|c|c|c|c|c|c|}
\hline & $\begin{array}{l}\text { Parcel } \\
\text { price }\end{array}$ & $\begin{array}{l}\text { Sale } \\
\text { rate }\end{array}$ & $\begin{array}{c}\text { Construction } \\
\text { expenses }\end{array}$ & $\begin{array}{l}\text { Land } \\
\text { cost }\end{array}$ & $\begin{array}{c}\text { Financial } \\
\text { cost }\end{array}$ & $\begin{array}{l}\text { Period } \\
\text { of } \\
\text { projects }\end{array}$ \\
\hline Parcel price & $(1,1,1)$ & $(1 / 3,1,3)$ & $(1 / 3,1,136,5)$ & $(1 / 7,1.065,3)$ & $(1,2280,3)$ & $(1,2599,5)$ \\
\hline $\begin{array}{l}\text { Sale } \\
\text { rate }\end{array}$ & $(1 / 3,1,3)$ & $(1,1,1)$ & $(1,1.968,5)$ & $(1,2590,5)$ & $(3,3,873,5)$ & $(3,4,213,7)$ \\
\hline $\begin{array}{l}\text { Construction } \\
\text { expenses }\end{array}$ & $(1 / 5,08800,3)$ & $(1 / 5,0.508,1)$ & $(1,1,1)$ & $(1,1.316,3)$ & $(1,2590,5)$ & $(3,3,409,5)$ \\
\hline $\begin{array}{l}\text { Land } \\
\text { cost }\end{array}$ & $(1 / 3,0.939,7)$ & $(1 / 5,0.386,1)$ & $(1 / 3,0760,1)$ & $(1,1,1)$ & $(1,1,732,3)$ & $(1,1.732,3)$ \\
\hline Financial cost & $(1 / 3,0.439,1)$ & $(1 / 5,0.258,1 / 3)$ & $(1 / 5,03866,1)$ & $(1 / 3,0.577,1)$ & $(1,1,1)$ & $(1,1.316,3)$ \\
\hline $\begin{array}{l}\text { Period of } \\
\text { projeds }\end{array}$ & $(1 / 5,03386,1)$ & $(177,0.237,1 / 3)$ & $(115,0.293,1 / 3)$ & $(1 / 3,0.577,1)$ & $(1 / 3,0,760,1)$ & $(1,1,1)$ \\
\hline
\end{tabular}

Table 4. Fuzzy matrix

The matrix shown in Table 4 is the result of the calculation using Eq.(3). Eq.(3) calculates a weight using 'Column Vector Geometric Mean Method.' The fuzzy weights calculated using Eq.(3) are in Table 5.

Table 5. Fuzzy weight

\begin{tabular}{ccc}
\hline Classification & Symbol & Fuzzy weight \\
\hline Parcel price (A1) & $\hat{\mathrm{W}}$ & $(0.0391,0.2039,0.8151)$ \\
Sale rate (A2) & $\hat{\mathrm{W}}$ & $(0.0936,0.3070,1.0222)$ \\
$\begin{array}{c}\text { Construction } \\
\text { expenses (A3) }\end{array}$ & $\hat{\mathrm{W}}$ & $(0.0547,0.1934,0.6788)$ \\
Land cost (A4) & $\hat{\mathrm{W}}$ & $(0.0413,0.1423,0.5490)$ \\
$\begin{array}{c}\text { Financial cost (A5) } \\
\text { Period of projects } \\
\text { (A6) }\end{array}$ & $\hat{\mathrm{W}}$ & $(0.0316,0.0833,0.2752)$ \\
\hline
\end{tabular}

According to Table 5, the calculation result of a vector $\left(\widehat{W}_{i}\right)$ is the $\operatorname{minimum}\left(\operatorname{Min} \widehat{W}_{i}\right)$, the geometric $\operatorname{mean}\left(\prod_{k=1}^{n} \widehat{W}_{i}\right)$ and the maximum $\left(\operatorname{Max} \widehat{W}_{i}\right)$, respectively.

$$
\begin{array}{r}
\widehat{A}_{i}=\left[\widehat{a_{i j}} \times \cdots \times \widehat{a_{\in}}\right]^{\frac{1}{n}} \\
\widehat{W}_{i}=\widehat{A}_{i} \times\left[\widehat{A}_{i}+\cdots+\widehat{A}_{n}\right]^{-1}--
\end{array}
$$

By using Eq. (4) for the geometric mean, the weighted vector was finally calculated. At this time, it was calculated to render the sum of weights calculated for risk factors to amount to 1 . 
The final weight(W) can be calculated as shown in Table 6.

$$
W_{i}=\sqrt[3]{\operatorname{Min} \widetilde{W}_{i} \times \prod_{k=1}^{n} \widetilde{W}_{i} \times \operatorname{Max} \widetilde{W}_{i}}
$$

Based on the result of the importance analysis in Table 6, the weights for parcel price(A1), sales rate(A2), construction expenses(A3), land price(A4), financial cost(A5), and period of the project(A6) are $0.187,0.309,0.193,0.148,0.093$, and 0.070 , respectively, and the sum of all weights is 1 .

Table 6. Final weight

\begin{tabular}{ccc}
\hline Classification & Symbol & Final weight \\
\hline Parcel price (A1) & W & 0.187 \\
Sale rate (A2) & W & 0.309 \\
Construction expenses & W & 0.193 \\
(A3) & W & 0.148 \\
Land cost (A4) & W & 0.093 \\
Financial cost (A5) & W & 0.070 \\
Period of projects (A6) & W & 1 \\
Sum & &
\end{tabular}

The importance of the risk factors for the apartment projects, in order, was shown to be sales rate (A2), construction expenses(A3), parcel cost(A1), land price(A4), financial cost(A5), and period of the project(A6), while in terms of direct risk factors, the importance, in order, was shown to be sales rate, construction expenses, parcel cost, land price, and financial cost.

\subsubsection{Weight of risk factors}

The weights shown in Table 7 indicate the importance of risk factors of the subcategory in the large category. To check the importance of the risk factors for the apartment projects, the total weight should be calculated. That is, the final importance of individual risk factors should be converted using $W_{F C} \times W_{F D}$. Here, $\mathrm{W}$ is weight, FC is the large category item, and FD is the subcategory item [20], and the results are indicated in Table 7.

As you can see in Table 7, of the risk factors for the feasibility analysis of the apartment projects, sales rate (A2) was considered most important. In addition, construction expenses (A3, 0.162), parcel price (A1, 0.158), land price(A4, 0.124 ), financial cost $(\mathrm{A} 5,0.078)$, and period of the project (A6, 0.059) were also considered important in the feasibility analysis. The risk factors derived in this study should be the most significant areas to review in a feasibility analysis,

Table 7. Weight of items

\begin{tabular}{|c|c|c|c|c|c|c|c|c|c|}
\hline \multirow{2}{*}{ Classification } & \multicolumn{3}{|c|}{ Fuzzy weight } & \multirow{2}{*}{ Final weight } & \multirow{2}{*}{ Classification } & \multicolumn{3}{|c|}{ Fuzzy weight } & \multirow{2}{*}{ Final weight } \\
\hline & Minimum & $\begin{array}{c}\text { Geometric } \\
\text { mean }\end{array}$ & Maximum & & & Minimum & Geometric mean & Maximum & \\
\hline \multirow{5}{*}{ A } & \multirow{5}{*}{0.4842} & \multirow{5}{*}{0.8472} & \multirow{5}{*}{1.4525} & \multirow{5}{*}{0.841} & A1 & 0.0391 & 0.2039 & 0.8151 & 0.187 \\
\hline & & & & & $\mathrm{A} 2$ & 0.0936 & 0.3070 & 1.0222 & 0.309 \\
\hline & & & & & A3 & 0.0547 & 0.1934 & 0.6788 & 0.193 \\
\hline & & & & & A4 & 0.0413 & 0.1423 & 0.5490 & 0.148 \\
\hline & & & & & A6 & 0.0229 & 0.0701 & 0.1908 & 0.070 \\
\hline \multirow{4}{*}{ B } & \multirow{4}{*}{0.0932} & \multirow{4}{*}{0.1528} & \multirow{4}{*}{0.2795} & \multirow{4}{*}{0.159} & B1 & 0.1457 & 0.3470 & 0.7624 & 0.338 \\
\hline & & & & & B2 & 0.0939 & 0.2303 & 0.5526 & 0.229 \\
\hline & & & & & B3 & 0.0753 & 0.1650 & 0.5441 & 0.190 \\
\hline & & & & & B4 & 0.0546 & 0.1446 & 0.3561 & 0.142 \\
\hline
\end{tabular}


and these are determined by the intertwining relationship between various factors, including the legal, systemic and economic environment.

Table 8. Risk influence factor weight count

\begin{tabular}{|c|c|c|c|c|}
\hline \multicolumn{2}{|c|}{ Classification } & No. & Weight & Ranking \\
\hline \multirow{4}{*}{$\begin{array}{l}\text { Direct Influence } \\
\text { factor } \\
\text { (A) }\end{array}$} & Parcel price & (A1) & 0.158 & 3 \\
\hline & Sale rate & (A2) & 0.260 & 1 \\
\hline & $\begin{array}{l}\text { Construction } \\
\text { expenses }\end{array}$ & (A3) & 0.162 & 2 \\
\hline & Land cost & (A4) & 0.124 & 4 \\
\hline \multirow{12}{*}{$\begin{array}{l}\text { Indirect Influence } \\
\text { factor } \\
\text { (B) }\end{array}$} & Financial cost & (A5) & 0.078 & 5 \\
\hline & Period of projects & (A6) & 0.059 & 6 \\
\hline & Apartment scale & (B1) & 0.054 & 7 \\
\hline & Apartment scale & (B1) & 0.054 & 8 \\
\hline & Position & (B2) & 0.036 & 8 \\
\hline & Position & (B2) & 0.036 & 9 \\
\hline & $\begin{array}{l}\text { Surrounding } \\
\text { comport condition }\end{array}$ & (B3) & 0.030 & 9 \\
\hline & $\begin{array}{l}\text { Surrounding } \\
\text { comport condition }\end{array}$ & (B3) & 0.030 & 10 \\
\hline & $\begin{array}{l}\text { Brand of origin } \\
\text { effect }\end{array}$ & (B4) & 0.023 & 10 \\
\hline & $\begin{array}{l}\text { Brand of origin } \\
\text { effect }\end{array}$ & (B4) & 0.023 & 11 \\
\hline & $\begin{array}{l}\text { Traffic environment } \\
\text { conditions }\end{array}$ & (B5) & 0.016 & 11 \\
\hline & Sum & & 1 & \\
\hline
\end{tabular}

\section{Conclusion}

While apartment development projects have been planned and executed even in significantly fluctuating social, cultural and economic conditions, the risk factors that should be considered in a feasibility analysis today have changed due to changes in the social attitudes toward consumption and housing, as well as changes in the population structure.

In this research, the risk factors were derived and the importance of the factors was calculated using FD-AHP. As a result, the risks are categorized into two large categories: direct risk factors and indirect risk factors. The direct risk factors include the 6 factors of parcel price, sales rate, construction expenses, land price, financial cost and period of the project, while the indirect risk factors include the 5 factors of adjacent region, traffic environment, surrounding comfort conditions, complex size and brand preference, for a total of 11 detailed risk factors. Of these, the most important, in order, were found to be sales rate(A2, 0.260), construction expenses(A3, 0.162), parcel cost(A1, 0.158), land price(A4, 0.124), financial cost(A5,0.078), and period of the project(0.059), suggesting that these are the factors that should be reviewed preferentially in a feasibility analysis.

In this study, the qualitative experience of the experts has been quantified using FD-AHP to select risk factors to be considered in a feasibility study of an apartment project. Therefore, reasonable implementation of an apartment project is expected when using the risk factors and considering the importance of the factors studied in this research. Lastly, it is expected that this study can be used as fundamental data for the development of a dynamic feasibility analysis model that can help project participants to monitor the changes in the relationships between diverse risk factors in an easier and more prompt manner.

\section{Acknowledgement}

This work was supported by the National Research Foundation of Korea(NRF) grant funded by the Korea government(MEST)(No. 2008-0061908)

\section{References}

1. Ko PS, Koh BS. Study on the Price of Housing depending on the Ordinary housing stability policy. Journal of Korea Electronic Communication Science. 2011 Apr;6(2):280-7.

2. Shin DH. A Risk Analysis Model for Apartment Building 
Project [dissertation]. [Yongin (Korea)]: KyungHee University; 2012. $141 \mathrm{p}$.

3. Yun HJ. A study of project financing for housing development in Korea. Journal of Korea Real Estimate Research. 2009 Dec;19(2):175-90.

4. Lee KH, Bang KS, Moon YK. Easing methods of credit enhancement requirements on real estate project finance loans by construction company. Journal of Residention Environment Institute of Korea. 2011 Dec;10(1):181-200.

5. Jeong $\mathrm{KH}$. Building a process model for feasibility analysis in an apartment housing development [dissertation]. [Yongin (Korea)]: KyungHee University; 2001. 68 p.

6. Shin WS, Park KJ. A Study on the Model for a Feasibility Study of an Apartment Project. Journal of Architectural Institute of Korea. 2005 Mar;21(3):153-60.

7. Kim KS, Lee JS, Huh YK. Development of Feasibility Analysis Model for Developer-requested Housing Projects. Journal of Construction Engineering and Management. 2009 Jun;9(3):117-25.

8. Shin KH, Kim JJ. A Study on the Importance of Risk Factors for Effective Risk Management in the Pre-Project Planning Phase of the Development Projects. Journal of Construction Engineering and Management. 2002 Jun;3(2):75-86.

9. Woo KM, Lee HK. A Study of the Risk Management on the Apartment Reconstruction Projects. Journal of Architectural Institute of Korea. 2005 Dec;21(12):175-82.

10. Kim JH, Lee SY. Evaluation of Risk Level in Real Estate Development Project based on Risk Factor Identification. Housing Studies Review. 2006 Feb;14(1):85-114.

11. Kim MH. A Study on the Method of the Risk Management in the Real Estate Development Project. Seoul (Korea): Construction Economy Research Institute of Korea; 2005. $114 \mathrm{p}$.

12. Lee JK, Lee JH. A Study on the Method of the Risk Management in the Housing Project. Journal of Korea Institute of Ecological Architecture and Environment. 2008 Apr;8(2):79-86.

13. Kwon $\mathrm{OH}$, Jung JH. An analysis of construction firms' feasibility study. Seoul (Korea): Construction Economy Research Institute of Korea; 2004. 119 p.

14. Hong JY. Risk-Based Feasibility Study of Residential Building Projects [dissertation]. [Chonnam (Korea)]: Chonnam National University; 2010. 172 p.

15. Kim SK, Joo JY, Kim KS. Feasibility Study Processes and Decision Making Methods of Urban Redevelopment Projects.
Journal of Construction Engineering and Management. 2004 Feb;5(1):71-9.

16. Ashworth A. Pre-contract Studies; Development Economics, Tendering and Estimating. $3^{\text {rd }}$ edition. Lodon: John Wiley and Sons Inc; 2008. 400 p.

17. Yoon SC, Yun SH, Paek JH. Forecasting Cash Flow by Considering Risk Factor in the Real Estate Development Project. Journal of Architectural Institute of Korea. 2006 Dec;22(12):165-72.

18. Koo SM, Jung MW. A Basic Study on the Current State and Problems of Feasibility Study : Focused on the Evaluation Criteria of the Existing Relative Researchest. Journal of Architectural Institute of Korea. 2007 Sep;23(9):79-88.

19. Zheng Q, Lee DH, Lee SH, Kim JT, Kim SK. A Health performance evaluation model of apartment building. Indoor Air Quality. 2011 Jan;20(1):26-35.

20. Lee SH, Zheng Q, Kim SK, Joo JK. Risk analysis on feasibility study of silver town projects. Journal of Architectural Institute of Korea. 2011 Aug;27(8):37-44. 